\title{
Characteristics of Acid Soluble Collagen from Catfish (Clarias Lazera) Skin
}

\author{
Hussein Abdelaal*, Hani Mohamed, Sanaa Salah, and Reem Elhosany \\ Food Science Department, Faculty of Agriculture, Minia University, Minia, Egypt \\ Corresponding Author: Hussein.galil@mu.edu.eg
}

\begin{abstract}
Fish wastes such as skin, scales, bones and fins are major by-products in the fishery and aquaculture industries have received significant attention in recent years as an alternative source of collagen. Acid-soluble collagen (ASC) was extracted from the skin of catfish (Clarias lazera). It was characterized in terms of chemical composition (moisture, protein, fat and ash content), Thermal denaturation temperatures (Td), solubility, SDSPAGE and amino acid analysis. The results indicated that the yield of ASC was $5.2 \%$ (wet weight basis). The chemical compositions of raw skin were $56.62 \%, 32.50 \%, 6.67$ and $2.93 \%$ while the chemical compositions of ASC $14.03 \%, 83 \%, 1.5 \%$ and $1.44 \%$ for moisture, protein, fat, and ash, respectively. The distinct absorption of collagen was obtained near $230 \mathrm{~nm}$. The Maximum solubility was $(3 \mathrm{mg} / \mathrm{ml})$ in $0.5 \mathrm{M}$ acetic acid at $\mathrm{pH} 2.5$. The denaturation temperature (Td) of ASC was $27^{\circ} \mathrm{C}$ and Hunter color L, a, and b values were 76.90, - 3.36 and 13.98 respectively. In conclusion, the characteristics of the isolated ASC indicate that catfish skin had good yield of collagen and it could be served as alternative source of collagen for some applications.
\end{abstract}

Keyword: Collagen, Catfish, Amino acid, denaturation temperature.

\section{Introduction}

Collagen protein generally produced from animal by-products which comprising approximately $25-30 \%$ of total protein. It is found in bones, tendons, ligaments, eye lenses, skin, and corneas, At least 29 different of collagen from a variety of animal tissues has been identified, and each type of collagen has its specific amino acid sequence and molecular structure (Sinthusamran et al., 2013). In recent years, acid extraction and pepsin hydrolysis was a common method used for extracting the collagen. Specifically, acetic acid has often been used as a solvent for the extraction of collagen (Jongjareonrak et al., 2005). Some researchers have addressed ways of obtaining collagen from different animal sources, such as bovine and pig and widely used in food, biomedical, cosmetic, and pharmaceutical industries, However, the outbreak of bovine spongiform encephalopathy (BSE) and the foot and- mouth disease (FMD) (Wang et al., 2014), In addition, collagen obtained from pork cannot be used in certain foods for religious reasons. Thus, there is need to find an alternative other source of collagen. Fish is one of the candidates' as such alternative source due to fish is unlikely to be associated with prion diseases. About $25-30 \%$ of fish processing waste consists of scale, skin, and bone, which are good source of collagen and have received more attention as collagen sources (Kittiphattanabawon et al., 2005). During the fish processing, a large amount of wastes, $50 \%$ to $70 \%$ of the original raw materials are generated, including skin, bone, viscera, and head from these residues, it is possible to produce collagen, with an important increased of fish waste value (Pati et al., 2010).

Egypt produced 36468 MT catfish equal $2.14 \%$ from total fish production (GAFRD, 2016). During fish processing, large amounts of byproducts, such as skins, head and bones, are discarded. Recently, collagens from several fish species have been isolated and characterized (Nagai and Suzuki 2000).

Fish collagens vary considerably in their amino acid composition. In particular, the levels of imino acids (proline and hydroxyproline) differ considerably from one fish species to another (Gudmundsson and Hafsteinsson, 1997). The amount of imino acids, in particular hydroxyproline, depends on the temperature of fish lives and influences the thermal stability of the collagens (Jongjareonrak et al., 2005). The aims of this study are to isolate and characterize acid soluble collagen (ASC) extracted from Nile catfish skin..

\section{Materials and Methods}

\section{1 fish skin preparation}

Life catfish (Clarias lazera) purchased from the fishery market and transported in ice to Food Science Laboratory Faculty of Agriculture Minia University. The average weight and length of the fish were 1500 g and $61 \mathrm{~cm}$, respectively. Fish samples washed with tap water. The catfish skins were removed manually, cut into to small pieces $(0.5 \times 0.5 \mathrm{~cm})$, washed with cold distilled water, packed in a polyethylene bag and stored at $-20^{\circ} \mathrm{C}$ until further use.

\subsection{Extraction of acid soluble collagen (ASC)}

Fish collagen was extracted using the methods of Zhang et al. (2009) with slight modification. All collagen extraction steps were performed at the temperature not higher than $7{ }^{\circ} \mathrm{C}$ (Hadfi and Sarbon, 2018).

The skin pieces were stirred in $0.1 \mathrm{M} \mathrm{NaOH}$ at a ratio of $1: 8(\mathrm{w} / \mathrm{v})$ for 24 hours for removing noncollagenous proteins and the extraction solution was changed every eight hr. The skins washed with cold distilled water until a neutral $\mathrm{pH}$ of 7 was achieved and defatting with 10 volumes of $10 \%$ butyl alcohol for $48 \mathrm{hrs}$. The defatted skins were washed with cold 
water and collagens were extracted by acetic acid solution (Kiew and Don, 2013).

$$
\text { Yield of collagen }=\quad \frac{\text { Weight of collagen }(\mathrm{g})}{\text { Weight of skin }(\mathrm{g})} \times 100 \%
$$

\subsection{Proximate analysis}

Moisture, protein, ash and total fat content were determined by AOAC (2000). A conversion factor 5.4 was used for calculating the protein content from nitrogen content.

\subsection{Protein concentration}

Protein concentration was measured with Lowry's method (Lowry et al., 1951); the protein standard was Bovine serum Albumin. Collagen concentration was quantified using (T80 UV-VIS-spectrophotometer) at 750

$\mathrm{nm}$.

\subsection{Characterization of the extracted collagen}

\subsubsection{UV-Vis measurement}

Collagen was scanned at wavelength ranged from 220 to $600 \mathrm{~nm}$ at room temperature according to (Anamdan et al., 2013)

\subsubsection{Amino Acid Analysis}

Collagen samples were hydrolyzed in $6 \mathrm{~N} \mathrm{HCl}$ at $110^{\circ} \mathrm{C}$ for $24 \mathrm{hr}$. and the hydrolysates were analyzed by HPLC an amino acid analyzer (Ishida et al., 1981). 2.5.3 SDS-Polyacrylamide Gel Electrophoresis (SDS-PAGE)

SDS-PAGE was performed according to the methods of Laemmli, (1970).

\subsubsection{Effect of $\mathrm{pH}$ on solubility:}

The effect of $\mathrm{pH}$ on the solubility of collagen was determined at $\mathrm{pH}$ range (1-10) according to method of Montero et al., (1991)

\subsubsection{Determination of collagen denaturation temperature}

The denaturation of collagen in solution was performed according to the method described by Pati et al. (2010) with slight modifications. A Brookfield viscometer beaker was filled with $0.3 \%(\mathrm{~m} / \mathrm{v})$ collagen solution in $0.05 \mathrm{M}$ acetic acid. Collagen solution viscosities were measure at temperature from $8^{\circ} \mathrm{C}$ up to $50^{\circ} \mathrm{C}$. Fractional viscosities were computed for each temperature. The fraction change was calculated from the viscosity measurement obtained with the below equation. Where, $\mathrm{C}$ is the collagen concentration $(\mathrm{mg} / \mathrm{mL}), \varepsilon 1$ is the viscosity at $8^{\circ} \mathrm{C}, \varepsilon 2$ is the viscosity at measured temperature $\left({ }^{\circ} \mathrm{C}\right)$ and $\varepsilon 3$ is the viscosity at $50^{\circ} \mathrm{C}$.

Fraction change $=[(\varepsilon 2 / \mathrm{C})-(\varepsilon 3 / \mathrm{C})] /[(\varepsilon 1 / \mathrm{C})-(\varepsilon 1 / \mathrm{C})-$ $(\varepsilon 3 / \mathrm{C})]$

The denaturation temperature was taken to be the temperature at which fractional viscosity was 0.5 .

\subsection{Color measurement:}

Sample was measured using a colorimeter (color Tec PCM colorimeter Tec. NJ, USA) five readings of each collagen sample were average for color measurement. The results were expresses as Hunter L (lightness), a (redness), and b (yellowness) color values. (Shon et al., 2011)

\section{Statistical analysis}

Three replicates were measured for each sample. All quantitative data were shown as the average \pm standard deviation.

\section{Results and discussion}

\subsection{Yield of extracted collagen from catfish skin}

Yield of extracted collagen from catfish skin. The yield of ASC from the skin of catfish was 5.2\% (wet weight basis) (table 1). This result was agreement with singh et al. (2011), who stated that the yield of ASC isolated from the skin of catfish $5.1 \%$ (based on the wet weight of skin). This result was similar to the yield of ASC extracted from bigeye snapper skin was $6.4 \%$ (wet weight basis (Kittiphattanabawon et al., 2005), whereas for brownstripe red snapper skin, the yield of ASC was $4.7 \%$ (wet weight basis) (Jongjareonrak et al., 2005). the yield of silver catfish was $10.49 \%$ (wet weight basis)

(Hukmi and Sarbon, 2019). This indicated that the skin of catfish can be a useful source of collagen.

Table 1. Yield of acid soluble collagen ASC and protein concentration from catfish skin

\begin{tabular}{lcc}
\hline sample & $\begin{array}{l}\text { Yield of acid } \\
\text { soluble collagen } \\
(\text { ASC) }(\%)\end{array}$ & $\begin{array}{c}\text { Protein } \\
\text { concentration } \\
(\mathrm{mg} / \mathrm{ml})\end{array}$ \\
\hline Catfish skin & 5.20 & $0.810 \pm 0.102$ \\
\hline
\end{tabular}

In this study Collagen in skin was solubilized to high extent by $0.5 \mathrm{M}$ acetic acid extraction Although skin contained high protein; the yield of collagen was relatively low $(5.2 \%)$. This result suggested a high amount of cross-links at the telopeptide region as well as other intermolecular cross-links, leading to low solubility of collagen in acid (Anandan et al., 2011). The protein concentration of (ASC) was $0.810 \mathrm{mg} / \mathrm{ml}$, one of the factors effected the protein concentration is the content of imino acid (proline + hydroxyproline) (Matmaroh et al., 2011). Thus, the higher protein concentrations in collagen may be attributed to higher levels of glycine, hydroxyproline and proline contained in the collagen (Hukmi and Sarbon, 2019).

\subsection{Proximate analysis of catfish skin}

Skin of catfish contained low moisture $(56.62 \%)$. thesis result lower than the skin from bigeye snapper contain a high moisture (64.08\%; Kittiphattanabawon et al., 2005), and balloon fish skin (62.23\%; Huang et al., 2011), whereas the Protein content in catfish was high in skin $(32.50 \%)$ based on the wet weight (Table 2). 
Table 2. Proximate composition of skin from catfish and the acid soluble collagen

\begin{tabular}{lcccc}
\hline Sample & Moisture & Protein & Fat & Ash \\
Catfish Skin & $56.62 \pm 0.387$ & $32.50 \pm 0.268$ & $6.67 \pm 0.190$ & $2.93 \pm 0.195$ \\
$($ ASC) Collagen & $14.03 \pm 0.480$ & $83 \pm 0.126$ & $1.5 \pm 0.246$ & $1.44 \pm 0.132$ \\
\hline \multicolumn{2}{c}{$(\mathrm{n}=3)}$, & $\pm=\mathrm{SD}$ & &
\end{tabular}

Muyonga et al., (2004) stated that the skin of Nile perch contained $20-22 \%$ of protein, which is lower than our study and agreement with (Kittiphattanabawon et al., 2005) who said the bigeye snapper skin contained $32 \%$ of protein. Lipid and ash contents in catfish skin are $6.67 \%$ and $2.93 \%$ (wet weight basis), respectively. Collagen sample had low moisture content $14.03 \%$. Furthermore the fat content for ASC was 1.5 \pm 0.246 .

The low fat amount in the isolated collagen showed an efficient defatting process. A study conducted by Shahiri et al. (2012) found only 0.31 (ASC) fat content in rainbow trout (Onchorhynchus mykiss) collagen.
However, Tan and sam (2017) recorded that the fat content for ASC of collagen isolated from Channel Catfish (Ictalurus punctatus) Skin was $0.92 \%$.

\subsection{Ultraviolet Spectra}

UV-Vis spectra of the extracted collagens, was an absorbance near 200-240 $\mathrm{nm}$. There was little or no absorption peak at $280 \mathrm{~nm}$. The results indicated that the high efficiency of non-collagenous protein removal. The absorbance in this region is similar to those of collagens extracted from channel catfish skin (Liu et al., 2007) and largefin longbarbel catfish (Zhang et al., 2009).

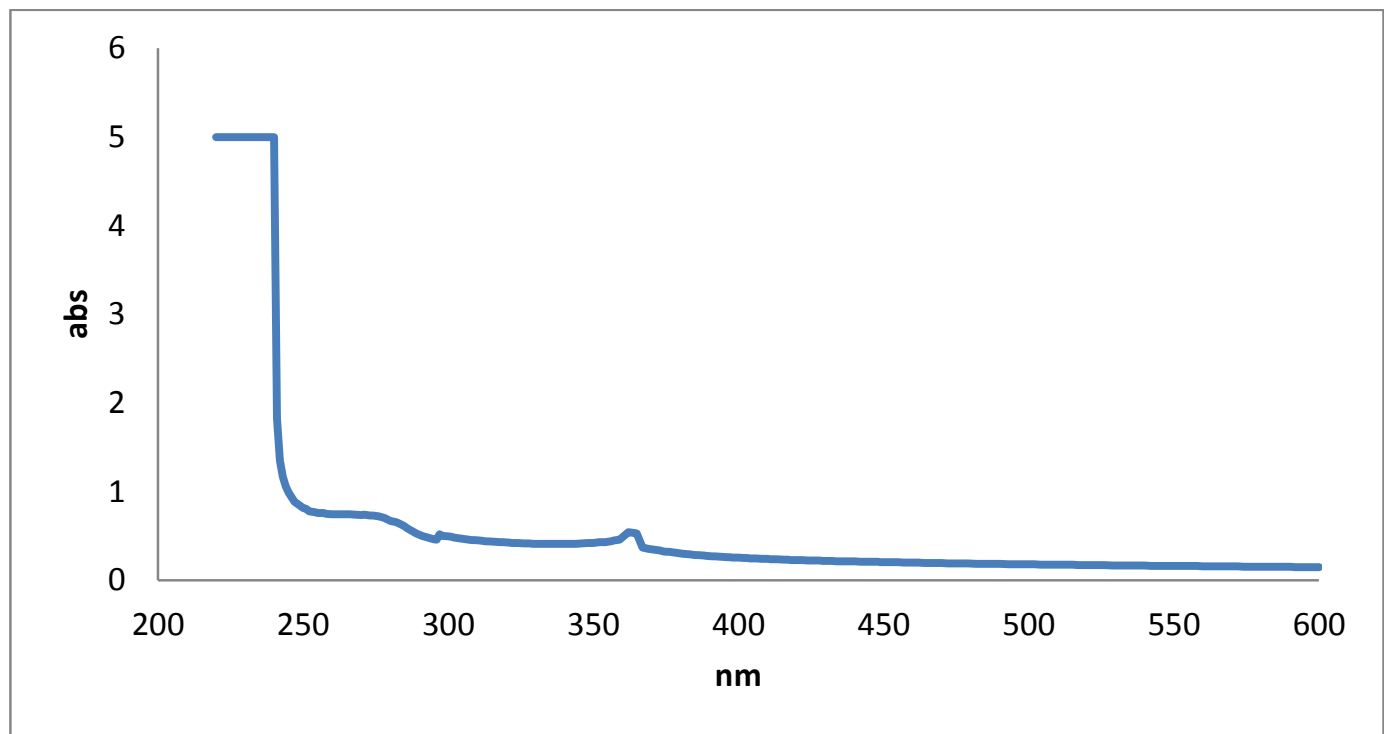

Fig.1: UV absorption spectrum of ASC from catfish skin

Previous research showed that collagen generally has a low amount of tyrosine which can absorb UVlight at $280 \mathrm{~nm}$ (Anandan et al., 2011], whereas, Tryptophan is completely absent in collagen and have negligible amount of tyrosine. Also, this result also proved that a product of high purity was obtained for ASC from catfish skin.

\subsection{Amino acid analysis}

Table 3 showed the amino acid content of the ASC extracted from the skin of catfish. The collagen was rich in glycine (228.5 residues) and alanine (102.1 residues) followed by proline, glutamic acid and hydroxyproline. It was also very low in cysteine, methionine and histidine, like other collagens (Gudmundsson and Hafsteinsson, 1997). The imino acid content of the ASC was 166.1 per 1,000 residues, which was similar to those of the balloon fish and ornate threadfin bream, (Huang et al., 2011 and Nalinanon et al., 2011), and lower than those of fish collagen such as grass carp skin collagen (186 residues/1000 residues) (Kittiphattanabawon et al., 2005).

Sikorski et al. (1984) reported that, the hydroxyproline content was commonly lower in fish collagen than animal collagen, which was a ranged 40-80 residues/1,000 amino acid residue in fish as compared to $100-130$ residues/1,000 amino acid residues in meat). Therefore the imino acid content of fish collagen was lower than those of mammalian collagens (Li et al., 2013). 
Table 3. Amino acid composition of catfish skin (ASC) collagen of catfish (amino acid residues per 1000 total amino acid residues).

\begin{tabular}{lc}
\hline Amino acid & Acid soluble collagen (ASC) \\
\hline Glutamic acid & 85.5 \\
Aspartic acid & 55 \\
Serine & 49 \\
Glycine & 228.5 \\
Histidine & 8.3 \\
\hline Arginine & 79.3 \\
Threonine & 36.1 \\
Alanine & 102.1 \\
Proline & 95.2 \\
Tyrosine & 26.7 \\
Valine & 22.2 \\
Methionine & 11.5 \\
Cysteine & 1.8 \\
Isoleucine & 11.7 \\
Hydroxyproline & 71.1 \\
Leucine & 26.7 \\
Phenylalanine & 19.8 \\
Lysine Imino acids & 69.6 \\
\end{tabular}

The amino acid content of collagen from catfish skin was almost similar to those of collagen from freshwater fish such as channel catfish and carp (Tan and Sam, 2017) and (Duan et al., 2009).

\subsection{SDS-PAGE of extracted (ASC) collagen:}

The result of electrophoretic analysis of ASC from catfish skin is shown in Fig.2. The lane 1 represents protein marker, while lane 2 consists of ASC protein fractions. The SDS-PAGE pattern showed that ASC consisted of two different $\alpha$ chains, $\alpha 1$ and $\alpha 2$, also contained of high molecular weight (MW) components including $\mathrm{b}$ and $\gamma$ components, $\alpha$ chains in the range of $109-130 \mathrm{kDa}$ similar to that reported by Hsieh et al., 2016). While $\beta$-dimer at $212 \mathrm{kDa}$ were similar to the results reported by Zhang et al. (2009). It was suggested that ASC isolated from catfish skin was probably type I collagen, which consisted of two $\alpha 1$ chains and one $\alpha 2$ chain. Similar result of electrophoretic of type I collagen from catfish skin was reported by Jongjareonrak, et al. (2005), (Nagai et al., 2008), trout (Montero et al., 1990), Nile perch (Muyonga et al., 2004), and bigeye snapper (Kittiphattanabawon et al., 2010). Muyonga et al., (2004) stated that the Type I skin collagen of Nile perch which consisted of two $\alpha 1$ and one $\alpha 2$ chains. Whereas Collagen extracted from Baltic cod skin had $\alpha$ chains with below $116 \mathrm{kDa}$ molecular weight (Skierka and Sadowska 2007).

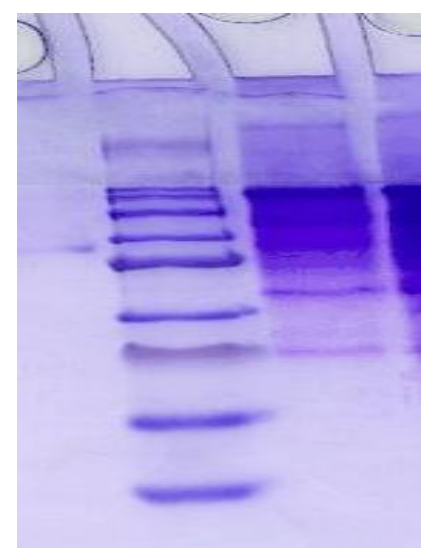

Fig. 2: SDS-PAGE patterns of ASC from the skin of catfish. Lane 1: protein markers; lane 2: collagen from skin.

\subsection{Effect of $\mathrm{pH}$ on collagen solubility}

ASC showed a maximum solubility at $\mathrm{pH} 2.5$ (fig 3).

This the data similar as the results reported by Jongjareonrak et al., 2005) and (Singh et al., 2011) for striped catfish. In general, collagen was solubilized in the acidic $\mathrm{pH}$ range (1-4) (Jongjareonrak et al., 2005). When the $\mathrm{pH}$ is higher or lower than isoelectric points, the net charge of protein molecules are better and the solubility is increased by the repulsion forces between chains (Vojdani, 1996). In contrast, when 
the hydrophobic-hydrophobic interaction increases, leading to the aggregation and precipitation at the $\mathrm{pI}$

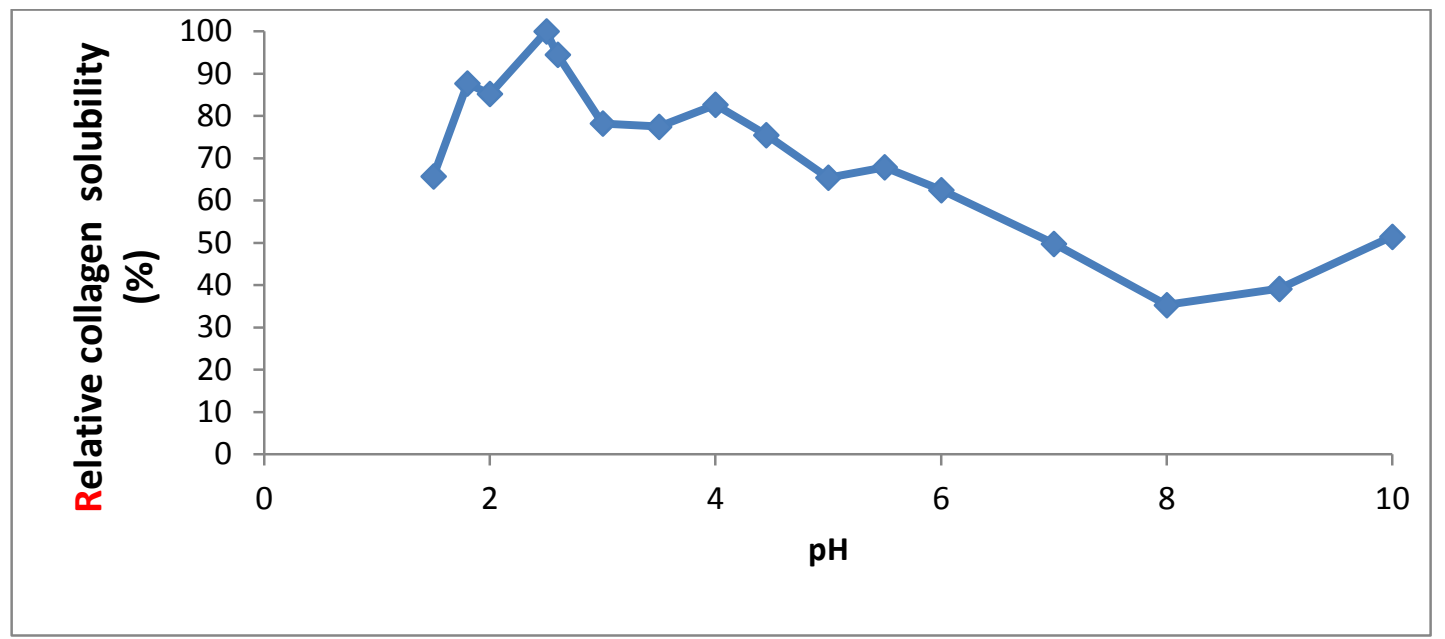

Fig. 3: Solubility of ASC from catfish skin in $0.5 \mathrm{M}$ acetic acid at different $\mathrm{pH}$

Foegeding et al., (1996) reported that collagen has isoelectric points ranging from $\mathrm{pH} 6$ to9. When $\mathrm{pH}$ increased from 7 to 10 , a slight increase in solubility of ASC was found. This might be due to the increased repulsion of collagen molecules with increasing negative charge (Hsieh et al., 2016). Thus, collagen was highl soluble in a very acidic $\mathrm{pH}$ range.

\subsection{Thermal denaturation temperature of collagen}

The Td of catfish skin collagen was found to be 27 ${ }^{\circ} \mathrm{C}$ (fig 3). This result was similar to the collagens from other fish skins, including bigeye Snapper (28.7
${ }^{\circ} \mathrm{C}$ ) (Kittiphattanabawon et al., 2005) and paper nautilus $\left(27{ }^{\circ} \mathrm{C}\right)$ (Nagai et al., 2002). On the other hand, The Td of collagen from the skin of catfish was higher than $\mathrm{Td}$ values of $16.1^{\circ} \mathrm{C}, 19.4^{\circ} \mathrm{C}$ were reported for Chum salmon muscle collagen (Kimura et al., 1988), Deepsea redfish skin (Wang et al., 2008)respectively. Generally, the $T d$ of collagen of fish living in cold environments is lower than the fish species living in warm environments (Duan et al., 2009)

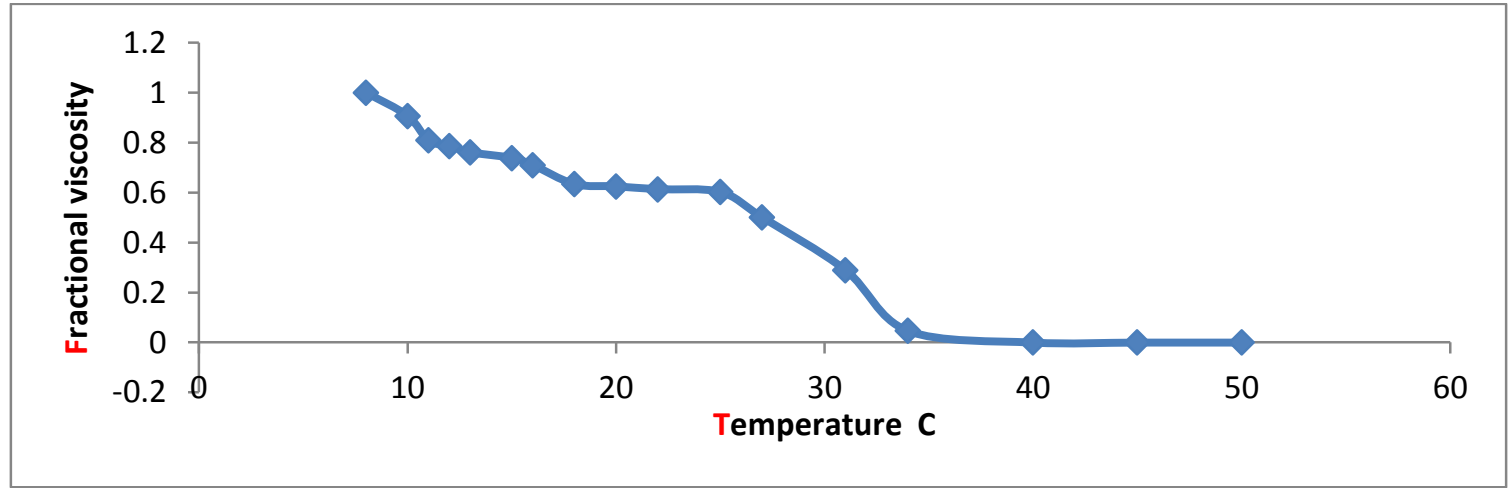

Fig.4: Thermal denaturation curve of acid -solubilized collagen of catfish skin

These results further proved that the helices of collagen from catfish skin had lower stability than those of mammalian collagens. The increasing of imino acid content resulted in increased denaturation temperature of the collagen (Piez and Gross, 1960). Collagen from fish waste generally lost its viscosity at approximately $50{ }^{\circ} \mathrm{C}$.

\subsection{Color measurements:}

The color values (L, a, b) of collagen powder extracted from catfish skin varied with pretreatment of collagen (Table 4). The color value L, which reflects lightness, was affected by the extraction solution, was 76.9 for collagen sample, indicating good visual whiteness. The collagen extracted from catfish skin had a white color. In respect to color the collagen is equal to commercial products. Therefore, collagen powder from catfish skin, if added in food products, is not likely to negatively impact the color of final products. The Hunter color b value was 13.98 for collagen sample. The Hunter color b value of catfish skin collagen increased as extraction time increased. 
Table 4. The Hunter color values of collagen powder extracted from catfish skin

\begin{tabular}{cccc}
\hline & $\mathrm{L}$ & $\mathrm{a}$ & $\mathrm{b}$ \\
\hline Skin collagen & $76,9 \pm 1.146$ & $-3.360 \pm 1.765$ & $13.98 \pm 0.865$ \\
\hline$(\mathrm{n}=3), \quad \pm=\mathrm{SD}$ & & &
\end{tabular}

A difference in the color values at different extraction solution is due to the protein denaturation and structural change by hydrolysis. One of the most important features of collagen, with regard to its use, is color (Skierka and Sadowska, 2007). Collagen entirely devoid of color is difficult to obtain due to the presence of pigment in fish skins. Leaching of catfish skins with $0.5 \mathrm{M}$ acetic acid $24 \mathrm{hr}$, followed by homogenization and centrifuging, leads to a colorless collagen solution (Shon et al., 2011).

\section{Conclusions}

ASC had protein concentrations $0.81 \mathrm{mg} / \mathrm{mL}$ the distinct absorption of collagen was obtained near 230 $\mathrm{nm}$. The Maximum solubility was $(3 \mathrm{mg} / \mathrm{ml})$ in $0.5 \mathrm{M}$ acetic acid at $\mathrm{pH} 2.5$. The denaturation temperature (Td) of ASC was $27{ }^{\circ} \mathrm{C}$ and Hunter color L, a, and b values were $76.90,-3.36$ and 13.98 respectively. In conclusion, the characteristics of the isolated ASC indicate that catfish skin had good yield of collagen and it could be served as an alternative source of collagen for some applications.

\section{Acknowledgement}

The authors are thankful to the Faculty of Agriculture Minia University for according permission to publish the paper. The assistance rendered by the technical staff of the Food Science Department the Institute is gratefully acknowledged.

\section{References}

Anamdan, R., Hema,G.S ., Shyni,k Mathew,S ., Ninan,G. lashmanan,P.T.(2013). Simple method for isolation of fish skin collagenbiochemical characterization of skin collgagen extracted from Albacore Tuna (Thunnus Alalunga), Dog Shark (Scoliodon Sorrakowah), and Rohu (Labeo Rohita). Annals of Biological Research, ):271-278.

AOAC International (2000). Official Method 928.08 Nitrogen in Meat. Gaithersburg, MD, USA: AssociationofAnalyticalCommunities 17thedition.

Duan, R., Zhang, J., Du, X., Yao, X., and Konno, K. (2009). Properties of collagen from skin, scale and bone of carp (Cyprinus carpio). Food Chemistry, 112, 702-706.

Foegeding, E., Lanier, T. C., and Hultin, H. O. (1996). Characteristics of edible muscle from yellowfin tuna (Thunnus albacores) dorsal skin. Food Hydrocolloid. 22: 879-887.

GAFRD. (2016). Fish statistics year book.

Gudmundsson, M., and Hafsteinsson, H. (1997). Gelatin from cod skins as affected by chemical treatments. Journal of Food Science. 62, 37 - 39.
Hamdan, F.S. and Sarbon, N.M. (2019). Isolation and characterisation of collagen from fringe scale sardinella (Sardinella fimbriata). International Food Research Journal, 26(1), 133 - 140.

Hsieh,C., Chyuan-Yuan Shiau, Yi-Cheng Su, YiHan Liu and Yu-Ru Huang (2016). Isolation and characterization of collagens from the skin of giant grouper (Epinephelus lanceolatus) Journal of Aquatic Food Product Technology 2016, Vol. 25, No. 1, 93-104.

Huang, Y. R., Shiau, C. Y., Chen, H. H., and Huang, B. C. 2011. Isolation and characterization of acid and pepsin solubilized collagens from the skin of (Diodon holocanthus). Food Hydrocolloid. 25: 1507-1513.

Hukmi, N.M.M. and Sarbon, N.M. (2018). Isolation and characterization of acid soluble collagen (ASC) and pepsin soluble collagen (PSC) extracted from silver catfish (Pangasius sp.) skin. International Food Research Journal, 25(5), 17851791.

Ishida, Y. T. Fujita and K. Asai, (1981). New detection and separation method for amino acid by high performance liquid chromatography. J. Chromatogr., 204: 143-148.

Jongjareonrak, A., Benjakul, S., Visessanguan, W., \& Tanaka, M. (2005). Isolation and characterisation of collagen from bigeye snapper (Priacanthus marcracanthus) skin. Journal of the Science of Food and Agriculture, 85, 1203-1210.

Kiew, P.L. and Don, M.M., (2013). The influence of Acetic Acid Concentration on the Extractability of Collagen from the Skin of Hybrid Clarias sp. And Its Physicochemical Properties: A Preliminary Study. Focusing on Modern Food Industry, 2 (3), pp. 123-128.

Kimura S, Zhu X, Matsui R, Shijoh M, Takamizawa, S. (1988). Characterization of fish muscle Type I collagen. J Food Sci 53 (5):13151318.

Kittiphattanabawon, P., Benjakul, S., Visessanguan, W., Kishimura, H., and Shahidi, F. (2010). Isolation and characterization of collagen from the skin of brownbanded bamboo shark (Chiloscyllium punctatum). Food Chem. 119: 1519-1526.

Kittiphattanabawon, P., Benjakul, S., Visessanguan, W., Nagai, T., and Tanaka, $M$. (2005). Characterisation of acid-soluble collagen from skin and bone of bigeye snapper (Priacanthus tayenus). Food Chemistry, 89, 363-372.

Laemmli, U. K. (1970). Cleavage of structural proteins during the assembly of the head 533 of bacteriophage T4. nature, 227, 680-685. 
Li, Z. R., Wang, B., Chi, C. F., Zhang, Q. H., Gong, Y. D., Tang, J. J., Luo, H. Y., \& Ding, G. F. (2013). Isolation and characterization of acid soluble collagens and pepsin soluble collagens from the skin and bone of Spanish mackerel (Scomberomorous niphonius). Food Hydrocolloids, 31(1), 103-113. Lebensm. Wiss. Technol. 40: 766-774

Liu, H. Y., Li, D., and Guo, S. D. (2007). Studies on collagen from the skin of channel catfish (Ictalurus punctaus). Food Chem. 101: 621-625.

Lowry, O. H., Rosebrough, N. J., Farr, A. L., and Randall, R. J. (1951). Protein measurement with Folin phenol reagent. Journal of Biological Chemistry, 193, 256-275.

Matmaroh, K., Benjakul, S., Prodpran, T., Encarnacion, A. B. and Kishimura, H. (2011). Characteristics of acid soluble collagen and pepsin soluble collagen from scale of spotted golden goatfish (Parupeneus heptacanthus). Food Chemistry 129(3): 1179-1186.

Montero, P., Jiménez-Colmenero, F., and Borderìas, J. (1991). Effect of $\mathrm{pH}$ and the presence of $\mathrm{NaCl}$ on some hydration properties of collagenous material from trout (Salmo irideus Gibb) muscle and skin. Journal of the Science of Food and Agriculture, 54(1), 137-146.

Muyonga, J. H., Cole, C. G. B., and Duodu, K. G. (2004). Extraction and physico chemical characterisation of Nile perch (Lates niloticus) skin and bone gelatin. Food Hydrocolloids, 18, 581-592.

Nagai, T. and N. Suzuki. (2000). Isolation of collagen from fish waste material - skin, bone and fins. Food Chem. 68: 277-281.

Nagai, T., Araki, Y., and Suzuki, N. (2002). Collagen of the skin of ocellate puffer fish (Takifugu rubripes). Food Chemistry 78: 173-177.

Nagai, T., Suzuki, N., and Nagashima, T. (2008). Collagen from common minke whale (Balaenoptera acutorostrata) unesu. Food Chemistry, 111, 296-301.

Nalinanon, S., Benjakul, S., Kishimura, H., and Osako, K. (2011). Type I collagen from the skin of ornate threadfin bream (Nemipterus hexodon): Characteristics and effect of pepsin hydrolysis. Food Chem. 125: 500-507.

Pati, F. Adhikari, B. Dhara, S. (2010). Isolation and characterization of fish scale collagen of higher thermal stability, Bioresour. Technol. 101, 37373742 .

Pranoto, Y., Lee, C.M., Park, H.J., 2007. Characterizations of fish gelatin films added with gellan and $\kappa$-carrageenan. LWT - Food Sci. Technol. 40 (5), 766-774.

Shahiri Tabarestani, H., Maghsoudlou, Y., Motamedzadegan, A., Sadeghi Mahoonak, A. R. and Rostamzad, H.( 2012). Study on some properties of acid-soluble collagens isolated from fish skin and bones of rainbow trout (Onchorhynchus mykiss). International Food Research Journal 19(1): 251-257.

Shon, Ji-Hyun Eo, Su Jung Hwang, and Jong-Bang Eun (2011). Effect of Processing Conditions on Functional Properties of Collagen Powder from Skate (Raja kenojei) Skins. Food Sci. Biotechnol. 20(1): 99-106.

Sikorski ZE, Scott DN, Bussion DH (1984). The role of collagen in the quality and processing of fish. CRC Crit Rev Food Sci Nutr 20 (4):301-338.

Singh, P., Benjakul, S., Maqsood, S., and Kishimura, H. (2011). Isolation and characterisation of collagen extracted from the skin of striped catfish (Pangasianodon hypophthalmus). Food Chem. 124: 97-105.

Sinthusamran, S.; Benjakul, S.; Kishimura, H. (2013). Comparative study on molecular characteristics of acid soluble collagens from skin and swim bladder of seabass (Lates calcarifer). Food Chem. 138, 2435-2441.

Skierka, E.and Sadowska, M. (2007). The influence of different acids and pepsin on the extractability of collagen from the skin of Baltic cod (Gadus morhua). Food Chem 105(3):1302-1306.

Tan,l and Sam, K.C. (2017). Isolation and Characterization of Collagen Extracted from Channel Catfish (Ictalurus punctatus) Skin. Food ChemistryS0308-8146(17)31472-3.

Vojdani, F. (1996). Solubility. In G. M. Hall (Ed.), Methods of testing protein functionality (pp. 1160). Great Britain: St. Edmundsbury Press.

Wang, L., An, X., Yang, F., Xin, Z., Zhao, L., and Hu, Q. (2008). Isolation and characterization of collagens from the skin, scale and bone of deepsea redfish (Sebastes mentella). Food Chem. 108: 616-623.

Wang, L., Liang, Q., Chen, T., Wang, Z., Xu, J. and Ma, H. (2014). Characterization of collagen from the skin of Amur sturgeon (Acipenser schrenckii). Food Hydrocolloids 38: 104-109.

Zhang, M., Liu, W., \& Li, G. (2009). Isolation and characterisation of collagens from the skin of largefin longbarbel catfish (Mystus macropterus). Food Chemistry, 115, 826-831. 


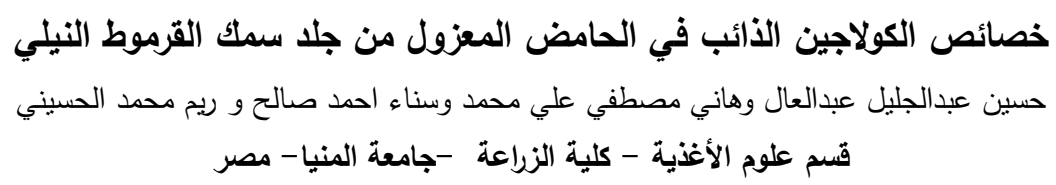

Corresponding Author: Hussein.galiı@mu.edu.eg

يستخدم الكولاجين فى العديد من التطبيقات فى الصناعات الغذائية و الطبية و الصيللانية لكن نظرا لتكلفته العالية اصبح محدود الاستخدام.

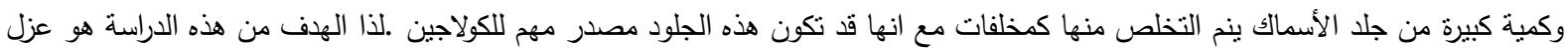
و دراسة صفات الكولاجين الذائب فى الحامض المستخلص من جلد سمك القرموط النيلى. حيث تم تقدير التركيب الكيمائي (الرطوبة البروتين الدهن.

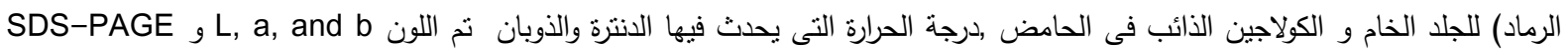
وامتصاص الضوء المرئي والغير مرئي و نحليل الاحماض الامينية للكولاجين الذائب فى الحامض. اظههرت النتائج ان نسبة تصافى الكولاجين الناتج

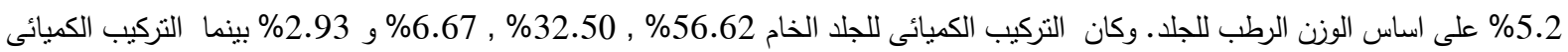

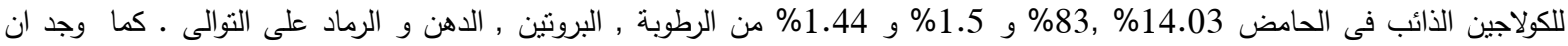

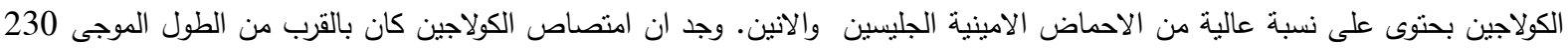

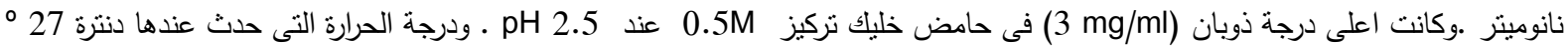

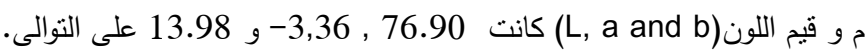
نستتنج من هذه الدراسة ان جلد سمك القرموط النيلي مصدر جيد للكولاجين ( الذائب فى الحامض) و يمكن استخدامه كمصدر بديل لإنتاج الكولاجين 